Ndalianis A., Neo-Baroque Aesthetics and Contemporary Entertainment, MIT Press, Cambridge 2005. Proctor W., Dark Knight Triumphant: Fandom, Hegemony and the Rebirth of Batman on Film, [w:] Fan Phenomena: Batman, red. L. Burke, Bristol Intellect Books, Chicago 2013.

Szyłak J., Komiks i okolice kina, Wydawnictwo Uniwersytetu Gdańskiego, Gdańsk 2000.

Wałaszewski Z., Wiedźmin: pierwszy polski supersystem rozrywkowy, [w:] Obraz literatury w komunikacji społecznej po roku '89, red. A. Werner, T. Żukowski, Wydawnictwo Instytut Badań literackich PAN, Warszawa 2013.

Żaglewski T., Kinowe uniwersum superbohaterów. Analiza współczesnego filmu komiksowego, PWN, Warszawa 2017.

\title{
Źródła internetowe
}

All Time Box Office, http://www.boxofficemojo.com/alltime/world/.

Fuller B., Here's Every Superhero Movie Releasing in 2018, http://screenrant.com/superhero-movies-2018-marvel-dc/.

Quattro K., The New Ages: Rethinking Comic Book History, https://web.archive.org/web/20150905115607/http://www.comicartville.com/newages.htm.

\author{
Ewa Nowak \\ ORCID: 0000-0002-1069-6705 \\ Uniwersytet Wrocławski
}

\section{Zmierzch antycznych igrzysk}

DOI: $10.19195 / 0867-7441.24 .26$

Recenzja: Sofie Remijsen, The End of the Greek Athletics in Late Antiquity, Cambridge University Press, Cambridge 2015, ss. 389.

Słowa kluczowe: antyczne igrzyska, agony, późna starożytność

Keywords: ancient olimpics, agones, late antiquity

Tradycja igrzysk sportowych, w tym najsłynniejszych igrzysk olimpijskich, sięga VIII wieku p.n.e. Starożytne zawody, choć utożsamiane przede wszystkim z okresem świetności polis greckich, odbywały się przez ponad dziesięć wieków, a prawdziwie „międzynarodowy” status zyskały w czasach cesarstwa rzymskiego, gdy w rejonie Morza Śródziemnego w cyklu dwu- lub czteroletnim miały miejsce rozmaite konkursy sportowe zwane po grecku agonami. Były one popularną rozrywką, która ściągała na stadiony rzesze ludzi, a najlepsi atleci zyskiwali sławę i pomniki na forach największych miast imperium. $\mathrm{Z}$ podobnym zaintere- 
sowaniem zawody sportowe spotkały się dopiero w XX wieku, wraz z odnowieniem tradycji olimpijskiej. Zwyczaj uprawiania ćwiczeń sportowych i oglądania zmagań atletycznych powoli zanikał w czasach późnej starożytności, ustępując miejsca nowemu podejściu do ciała i rozrywki. Ten ostatni etap greckiej kultury agonicznej znalazł się w centrum zainteresowań badaczki starożytności Sofie Remijsen. Autorka książki The End of the Greek Athletics in Late Antiquity pokazuje, jak funkcjonowały agony w okresie poprzedzającym ich upadek oraz jak wyglądał proces przemijania igrzysk sportowych i całej kultury, która przez wieki była z nimi związana.

Remijsen nie jest pierwszym badaczem, który porusza te kwestie. W ostatnich latach pojawiło się wiele nowych opracowań na temat sportu w starożytności ${ }^{1}$, kilka bardziej szczegółowych prac dotyczy także późnego antyku ${ }^{2}$. Problematyka ta, choć już omawiana, nie doczekała się uprzednio obszernej monografii zbierającej dotychczasowe ustalenia i próbującej ująć temat w świetle najnowszych badań z zakresu archeologii, filologii klasycznej, historii i historii sztuki. Praca Remijsen, będąca rozszerzoną wersją jej rozprawy doktorskiej, podzielona została na dwie części. Pierwsza część, bardziej analityczna, poświęcona jest agonom w poszczególnych regionach imperium, druga ma charakter syntetyczny - autorka na podstawie dokonanych analiz próbuje wyjaśnić procesy, które doprowadziły do upadku agonów. Część pierwszą poprzedza rozbudowane wprowadzenie, w którym szczegółowo przedstawiony został dotychczasowy stan badań uwzględniający podejście do tematu poszczególnych badaczy począwszy od wie$\mathrm{ku}$ XIX. Remijsen pokazuje, jak istotną rolę w postępie badań odegrały wykopaliska prowadzone na terenach dawnych obiektów sportowych, szczególnie w Olimpii. Zainteresowania archeologów i historyków początkowo skupiały się głównie na okresie archaicznym i klasycznym, gdyż większość badaczy przekonana była, że tylko w niezależnych miastach greckich w pełni rozkwitać mogły zawody agonistyczne. W badaniach historyczno-społecznych przeważał bowiem następujący model: powstanie i rozwój-złoty wiek-upadek. Taki schemat obowiązywać miał też w ramach kultury agonów, toteż wraz z nastaniem epoki hellenistycznej zawody przeżywać miały swój zmierzch. Poza tym w nauce przeważało mylne przekonanie, że do roku 400 p.n.e. sportowcy byli amatorami. Amatorstwo to postrzegano zaszczytnie i rozpatrywano w kategoriach złotej, idealistycznej ery zawodów okresu archaicznego i klasycznego. Zgodnie z tym założeniem sport

${ }^{1}$ Dla przykładu dwie z nowszych pozycji traktujące o całej starożytności: D. Kyle, Sport and Spectacles in Ancient Word, Oxford-Malden 2007; D. Potter, The Victors Crown: A History of Ancient Sport from Homer to Byzantium, Oxford 2012.

${ }^{2} \mathrm{Na}$ przykład F. Camia, Spendings on the agones. The Financing of Festivals in the Cities of Roman Greece, „Tyche” 2011, nr 26, s. 41-76; R.F. de Voe, The Christians and the Games: The Relationships between Christianity and Roman Games from the First through the Fifth Centuries, $\mathrm{PhD}$ diss. Texas Tech University 1987; A. Farrington, Olympic Victors and the Popularity of the Olympic Games in the Imperial Period, „Tyche” 1997, nr 12, s. 15-46. 
stał się profesjonalny dopiero w okresie poklasycznym ${ }^{3}$. Autorka pokazuje, jak dalsze postępy w badaniach, szczególnie rozwój badań nad epigrafiką, przełamały dotychczasowe myślenie. Przytacza także prace poświęcone późnej starożytności, które przyczyniły się do lepszego zrozumienia tej epoki ${ }^{4}$. Remijsen opisuje stopniową zmianę paradygmatu — zamiast modelu rozwoju i upadku pojawił się model transformacji i adaptacji kulturowej. W tym też duchu prowadzone były dalsze badania nad agonami, które doprowadziły jednak do pewnego impasu, bo jeśli okres rzymski to nie kres agonów, lecz wręcz przeciwnie — czas prawdziwej eksplozji, jak pokazały bogate źródła epigraficzne, to kiedy właściwie przyszedł kres zawodów? Z tym nurtującym pytaniem autorka pozostawia na razie czytelnika i przechodzi do szczegółowego omówienia materiału źródłowego (s. 14-25).

Zaczyna od źródeł epigraficznych (inskrypcje honorujące organizatorów igrzysk) i numizmatycznych (monety upamiętniające zwycięzców z poszczególnych miast). Zaznacza jednak, że brak obu przekazów nie może być argumentum ex silentio za upadkiem agonów. Nie jest on bowiem warunkowany spadkiem zainteresowania zawodami, ale zmianami ekonomiczno-społecznymi. Pod koniec III wieku miasta przestają bić własne monety, a liczba inskrypcji spada w całym imperium, zanika też zwyczaj umieszczania inskrypcji honorujących elity odpowiedzialne za organizacje igrzysk. Kolejne z omawianych źródeł to papirusy (Remijsen zaznacza, że informacje w nich zawarte ograniczają się głównie do Egiptu) i teksty literackie. Bogata metaforyka agoniczna obecna w literaturze antycznej nie obrazuje przemian samego zjawiska, ale dla późnego antyku istotne są jednak teksty chrześcijańskie zawierające krytykę agonów. Autorka podkreśla także ważność świadectw archeologicznych, które pokazują, kiedy dane obiekty przestały być używane lub przestały pełnić swą dotychczasową funkcję. Korzysta również z badań z zakresu historii sztuki; na uwagę zasługują przede wszystkim przedstawiające atletów mozaiki.

Pierwsza część książki rozpoczyna się krótką historią greckich igrzysk. Autorka zaznacza, że od czasów archaicznych składały się na nie zawody sportowe, wyścigi rydwanów i konkursy artystyczne, jednakże nie każdy z tych elementów musiał być obecny. Organizowane były przez greckie miasta i do V wieku ustaliła się hierarchia poszczególnych imprez na czele z igrzyskami olimpijskimi, delfickimi, nemejskimi i istmijskimi. Agony popularne były też w państwach hellenistycznych — grecki styl bycia rozpowszechniony był wówczas wśród elit. W czasach rzymskich stały się prawdziwym fenomenem na skalę całego niemal-

${ }^{3}$ Myśl tę zapoczątkował w XIX wieku irlandzki filolog i historyk John Pentland Mahaffy, później nawiązywało do niej wielu badaczy. W wydanej po raz pierwszy w roku 1911 poczytnej książce The Glory That Was Greece John Clarke Stobart podkreślał, że sportowcy byli amatorami, a nagrodą w zawodach była wyłącznie sława (J.C. Stobart, The Glory That Was Greece, Philadelphia-London 1911, s. 78).

${ }^{4}$ Na przykład The Cultural Turn in Late Ancient Studies: Gender, Asceticism et Histography, red. D.B. Martin, P. Cox Miller, Durham 2005. 
że imperium — najważniejsze igrzyska tworzyły zwarty system, umożliwiający sportowcom partycypację we wszystkich ważnych zawodach. Autorka pokazuje, jak wyglądać mógł objazd sporowca po igrzyskach w cyklu czteroletnim, część igrzysk odbywała się bowiem co dwa, część co cztery lata.

W kolejnych rozdziałach została przedstawiona sytuacja agonów w poszczególnych rejonach imperium, ze szczególnym uwzględnieniem czasów późniejszych, czyli od końca III wieku naszej ery (s. 33-163). Analizując różnorodny materiał źródłowy, autorka pokazuje, jak wyglądały igrzyska w Grecji, Azji Mniejszej, Syrii, Egipcie, na Sycylii, w Italii, Galii i w Afryce Północnej. Zaznacza, kiedy na danych terenach pojawiły się agony, a kiedy obserwować można ich zanik oraz jaka była specyfika kultury sportowej i zawodów w poszczególnych regionach.

Podsumowaniu części pierwszej towarzyszą następujące konkluzje: 1. większość agonów organizowana była jeszcze w pierwszym kwartale IV wieku, 2. wyraźny kryzys i zaprzestanie organizacji igrzysk przypada dopiero na drugi kwartał IV wieku, 3. problemy czterech głównych igrzysk przyczyniły się do załamania całego systemu, który był do nich dostosowany, 4. przez cały czas istnienia agonów program zarówno rozgrywek sportowych, jak i wydarzeń im towarzyszących pozostawał bez większych zmian ${ }^{5}, 5$. w IV wieku w imperium w sektorze rozrywkowym największą popularnością cieszyły się wyścigi rydwanów, nawet na terenach, na których uprzednio zdecydowanie dominowały zawody agoniczne, przez co część atletów stała się częścią świata rozrywki skupionego wokół wyścigów.

W części drugiej zatytułowanej Agones in a changing world Remijsen zastanawia się, jak religijno-polityczna sytuacja późnego imperium przyczyniła się do zaniku tradycji agonicznej. Analizuje także zmiany w mentalności i obyczajowości epoki, które w dużej mierze wpłynęły na stosunek ówczesnych ludzi zarówno do uprawiania sportu, jak i samych wydarzeń sportowych. Odwołując się do przytoczonego we wstępie paradygmatu transformacji kulturowej, zastanawia się, które elementy agonów mogły zostać zaadaptowane do nowych warunków, a które się nie zmieniały.

Rozdział ósmy A religious ban? (s. 181-197) zawiera rozważania na temat wpływu chrześcijaństwa na postrzeganie agonów w później starożytności. Igrzyska niewątpliwie miały charakter religijny i związane były ze światem tak zwanej religii pogańskiej. Remijsen zastanawia się, w jakiej mierze czynności rytualne towarzyszące agonom mogły ulec sekularyzacji. Uczty i procesje, będące nieodłącznym elementem igrzysk, w drugiej połowie IV wieku zyskały świecki charakter, a wraz z cesarskimi rozporządzeniami ofiary i ołtarze zostały usunięte, jednak w przypadku takich agonów jak w Olimpii związek ze świątynią był zbyt tradycyjny i oczywisty. Autorka podkreśla, że pisarze chrześcijańscy, jak Ter-

${ }^{5} \mathrm{O}$ zmianach w charakterze niektórych elementów igrzysk Remijsen pisze dalej w rozdziale ósmym. 
tulian czy Jan Chryzostom, krytykowali agony, aczkolwiek od końca IV wieku większość zarzutów nie była skierowana przeciwko pogańskim korzeniom tych uroczystości, lecz swawolnemu charakterowi wszelakich widowisk, w tym także sportowych.

W rozdziale dziewiątym An imperial ban? (s. 198-219) przedstawiona zostaje polityka cesarzy wobec agonów. Autorka podkreśla, że zawody sportowe miały ściśle ustalony grafik i władca nie mógł zorganizować ich ad hoc, dlatego nigdy nie były tak korzystnym narzędziem do ukazania cesarskiej władzy jak inne igrzyska „w stylu rzymskim” — wyścigi cyrkowe czy polowania. Jednak powołanie nowych igrzysk i ustalenie ich statusu zależało od decyzji cesarskiej. Była to więc decyzja, która w dużej mierze rzutowała na stosunki między miastami, organizatorami igrzysk, a cesarzem. Autorka powołuje się na zachowaną korespondencję dotyczącą igrzysk, dowodząc, że nie ma świadectw potwierdzających zakaz organizowania agonów przez cesarzy. Odnaleźć można jedynie petycje i delegacje miast w sprawie problemów z ich finansowaniem. Jedyny agon, o którym wiadomo z całą pewnością, że został zakazany przez cesarza, to zawody w Antiochii. Jednak jest to casus dopiero z VI wieku.

Rozdział dziesiąty The athletic professionals (s. 220-251) poświęcony jest nakreśleniu sylwetki profesjonalnego sportowca — człowieka dobrze urodzonego i majętnego, który mógł pozwolić sobie na czasochłonny trening i kosztowne podróże. Autorka podkreśla, atletyka nie była postrzegana jako forma zarobku, i pokazuje różnice między nagrodą w zawodach a zwykłym wynagrodzeniem za pracę. Przedstawia także sytuację sportowców w późnej starożytności: atleta, który wybrał sportową karierę, nie był stawiany na równi z atletą nieuczestniczącym w profesjonalnych agonach i niezwiązanym z sektorem rozrywkowym. Remijsen stwierdza, że wraz z upadkiem agonów część atletów prawdopodobnie inkorporowana została do popularnych wówczas frakcji cyrkowych.

W kolejnym rozdziale Athletics as an elite activity (s. 252-288) autorka pokazuje, że uprawianie ćwiczeń sportowych, w przeciwieństwie do ich oglądania, było przede wszystkim zajęciem elit. Zarysowuje obraz edukacji sportowej w Grecji, ukazuje wysiłek fizyczny w świetle greckiej paidei (wzoru wychowania), odwołuje się do takich kategorii jak ponofillia (umiłowanie trudu). Celem tych rozważań jest prezentowanie zmian w obyczajowości późnego antyku. W IV wieku ćwiczenia fizyczne stają się mniej ważne, a palestry (miejsca ćwiczeń) znikają z łaźni. W dużej mierze przyczynił się do tego światopogląd chrześcijański. Atletyzm jako forma kontroli nad ciałem przez jego doskonalenie wyparty został przez ascetyzm, który nakazywał zmarginalizowanie potrzeb ciała i tym samym uzyskanie umysłowej dominacji nad fizycznością. Ambicje, które grały główną rolę w zawodach sportowych, zastąpione zostały ideami chrześcijańskiej pokory, a wysportowane nagie ciało było utożsamiane z próżnością. W rozdziale tym poruszona zostaje także kwestia synodu agonistycznego, organizacji reprezentującej interesy sportowców oraz innych, lokalnych instytucji zrzeszających atletów. 
Rozdział dwunasty The practical organization of agones (s. 389-320) poświęcony jest organizacji agonów. Autorka odpowiada na pytania: od kogo wychodziła inicjatywa organizacji agonów, w jaki sposób były one finansowane i jak ustalano ich status. Skupia się przede wszystkim na późnym antyku: na zmianach w kwestii organizacji nowych agonów i problemach w zapewnieniu kontynuacji już istniejących. Pokazuje, jak reformy administracyjne wpłynęły na ukształtowanie nowych priorytetów wśród lokalnych elity, dla których wykazanie się przy organizacji agonów przestało być istotne.

W ostatnim rozdziale The agon as spectacle (s. 321-342) przedstawione są różnice w postrzeganiu agonu w świecie kultury greckiej i rzymskiej. Nakreślona zostaje pozycja „osoby występującej przed innymi” w kulturze rzymskiej, z odwołaniem się do tak zwanej infamii, czyli złej sławy, która dotykała ludzi z sektora rozrywkowego. Poruszono ważne kwestie greckiego i rzymskiego nazewnictwa, które obrazują różnice kulturowe. W rezultacie autorka podkreśla, że greckie agony stały się z czasem rzymskimi spectacula, a atletyka zwykłą formą pracy zarobkowej.

Konkluzje wieńczące część drugą są zestawieniem wszystkich dotychczasowych ustaleń i zarysowaniem sytuacji agonów w przededniu ich upadku. Pokazano także, jaki los spotkać mógł sportowców, którzy próbowali do końca zachować wierność kulturze agonów.

Książka skierowana jest bez wątpienia do osób obeznanych ze starożytnością i językami klasycznymi. Większość cytatów z łaciny i greki, podobnie zresztą jak z francuskiego i niemieckiego, nie jest tłumaczona na język angielski, tylko kilka dłuższych passusów opatrzonych zostało przekładami. Autorka oczekuje też od czytelnika podstawowej wiedzy na temat antycznych igrzysk sportowych, wielokrotnie odwołuje się bowiem do poszczególnych konkurencji, podając wyłącznie ich greckie nazwy i nie wyjaśniając zasad ich rozgrywania.

Mimo specjalistycznego charakteru tekstu wywody Remijsen są bardzo klarowne. Jest to w dużej mierze zasługą kompozycji książki. Dokładne przedstawienie sytuacji agonów w części pierwszej umożliwia zrozumienie ich problematyki i jest odpowiednim wprowadzeniem do rozważań na temat ich upadku. W części drugiej autorka thumaczy zarysowaną uprzednio sytuację historyczną, pokazując zestaw bezpośrednich i pośrednich czynników, które mogły wpłynąć na kondycję igrzysk w późnej starożytności, ze szczególnym uwzględnieniem przemian o charakterze obyczajowym. Obie części wzajemnie się uzupełniają, umożliwiając czytelnikowi zrozumienie kultury agonów i zjawisk związanych z jej upadkiem. Komplementarność ta oznacza jednak, że poszczególne rozdziały nie zawsze tworzą pełen obraz omawianego zagadnienia. Na przykład w części pierwszej w rozdziale poświęconym zawodom w Grecji autorka analizuje przekazy dotyczące wydanego przez Teodozjusza zakazu zawodów w Olimpii (s. 47-51) i do kwestii tej nie powraca już w rozdziale ósmym, który poświęcony jest polityce cesarzy wobec igrzysk. 
Rozważając problematykę agonów, Remijsen porusza także interesujące kwestie specyfiki rozrywki w cesarstwie rzymskim. Pokazuje, co w danym czasie warunkowało popularność poszczególnych widowisk i jak zmiany zainteresowań oraz upodobań ówczesnych ludzi rzutowały na kondycję agonów.

Precyzyjny i przejrzysty jest także język książki. Wprawdzie zawiera ona wiele terminów fachowych, jednakże praca nie jest przeładowana nadmierną naukowością, a sama autorka daleka jest od wyszukanej, słownej ekwilibrystyki. Wykorzystała wiele prac, zarówno najnowszych, jak i od lat uznanych w nauce. Bibliografia jest więc bardzo obszerna i stanowi odpowiednie uaktualnienie obecnego stanu badań. Liczne, szczegółowe przypisy umożliwiają dokładne zapoznanie się zarówno ze źródłami, jak i poglądami badaczy. Należy zwrócić także uwagę na stopień oryginalności książki. Remijsen przyznaje, że temat upadku agonów jest już omawiany w literaturze, ale dotychczas nie został przedstawiony całościowo, a niektóre stanowiska badaczy należało zrewidować. Dokładnie analizuje i uzupełnia dotychczasowe ustalenia. Co istotne, stara się pokazać kryzys agonów był już omawiany i procesów późnej starożytności, dlatego praca ta stanowi również wnikliwe studium nad schyłkowym antykiem. Książka Remijsen jest zarówno podsumowaniem, jak i kolejnym etapem badań nad kulturą fizyczną w późnej starożytności.

\section{Bibliografia}

\section{Opracowania}

Camia F., Spendings on the agones: The financing of festivals in the cities of Roman Greece, „Tyche" 26, 2011.

Farrington A., Olympic Victors and the Popularity of the Olympic Games in the Imperial Period, Tyche 12, 1997.

Kyle D.G., Sport and spectacles in Ancient Word, Oxford-Malden 2007.

Potter D., The Victors Crown: A History of Ancient Sport from Homer to Byzantium, Oxford 2012.

Voe de R.F., The Christians and the Games: The Relationships between Christianity and Roman Games from the First through the Fifth Centuries, PhD diss. Texas Tech University 1987. 